\title{
Service Quality Dimension in Health Care Service Delivery: The Case for Healthstrat in Kenya
}

\author{
Janet Mukami Mugambi, Zipporah N. Kiruthu
}

School of Business Studies, University of Nairobi, Nairobi, Kenya

\section{Email address:}

mukami.mugambi@gmail.com (J. M. Mugambi)

\section{To cite this article:}

Janet Mukami Mugambi, Zipporah N. Kiruthu. Service Quality Dimension in Health Care Service Delivery: The Case for Healthstrat in Kenya. Science Journal of Business and Management. Vol. 3, No. 5, 2015, pp. 164-174. doi: 10.11648/j.sjbm.20150305.15

\begin{abstract}
The main objective of this study was to investigate service quality dimension in health care service delivery, the case for Healthstrat. In doing so, the study adopted the following objectives: to investigate the factors that determine service delivery at Healthstrat, to investigate the customers' service expectations at Healthstrat and to determine the impact of service delivery mechanism on service quality. The study was guided by the SERVQUAL model which was made of ten dimensions of service quality when created; tangibles, reliability, responsiveness, communication, credibility, security, competence, courtesy, understanding the customer, and access, but later on these dimensions were reduced to five because some dimensions were overlapping (communication, credibility, security, competence, courtesy, understanding customers and access) and they included, Tangibles- physical facilities, equipment, and staff appearance. The study adopted a descriptive research design method. The target population of this study consisted of all the 98 employees working at the hospitals that Healthstrat supports and a sample size of 30 employees was considered. The study used primary data collected through a structured questionnaire. Data was analysis using statistical package for social sciences. Descriptive statistics such as mean, standard deviation were generated. The study found out that service quality as perceived by customers is as a result of how well service matches expectations. Secondly that service quality was determined by two dimensions, namely; expectations and experience and each of these dimensions had underlying factors. Thirdly, five factors determined the outcome of service quality which is used by the customers to complete judgement during service delivery, namely; tangibles, reliability, responsiveness, assurance and empathy. The study recommends that participants mentioned the staff to be the focus of improvement based on the fact that it's the service staff that actually operationalizes service quality standards and more importantly it's during the service encounter where the customer forms the last judgements on service quality.
\end{abstract}

Keywords: Service Quality, Healthstrat, SERVQUAL Model, Service Delivery

\section{Introduction}

\subsection{Background of the Study}

Service quality is a comparison of expectations with performance. A business with high service quality will meet customer needs whilst remaining economically competitive. Improved service quality may increase economic competitiveness. This aim may be achieved by understanding and improving operational processes; identifying problems quickly and systematically; establishing valid and reliable service performance measures and measuring customer satisfaction and other performance outcomes (Caron and Giauque, 2006).

According to Clinton, Williamson and Bethke, (2004) since Service Quality is the universal concept of providing service quality, the company will be able to increase its' revenue, improved customer service and customer loyalty (Ladhari, 2009). Athanassopoulos, (2010) affirmed the relations between customer satisfaction and company profit in their research. Therefore, it is important for any company to concentrate on improving their customer service. The quality of the service is important for both, consumers and service provider Companies. Without any doubt, customers will choose the company which provides them best goods or quality services. Moreover, nowadays the customers are becoming more and more demanding as for the development of service quality as well as the number of service companies. Customers have more choices to buy the services, which is why it is important for every organization to stand solid among other competitors to get the business. Thus, the competitions between the service companies become very 
tough. Fortunately, "service marketers have experienced it for past few years that competition can be well managed by differentiating through quality", moreover "the importance of service lies in customer service management" (Ladhari, 2009). Any company should be able to generate the sufficient sales and retain the customers in order to survive in the competition. The only way is to provide quality service to the customers at a favorable cost.

\subsubsection{Service Quality}

Service quality is considered an important tool for a firm's in a competitive environment to differentiate itself from its competitors (Ladhari, 2008). The relevance of service quality to companies is emphasized especially the fact that it offers a competitive advantage to companies that strive to improve it and hence bring customer satisfaction. Service quality has received a great deal of attention from both academicians and practitioners (Negi, 2009) and services marketing literature service quality is defined as the overall assessment of a service by the customer (Eshghi, Roy, \& Ganguli, 2008). Ghylin., Green, Drury, Chen, Schultz, Uggirala, Abraham, \& Lawson, (2006) points out that, by defining service quality, companies will be able to deliver services with higher quality level presumably resulting in increased customer satisfaction. Understanding service quality must involve acknowledging the characteristics of service which are intangibility, heterogeneity and inseparability, (Parasuraman, Zeithaml, \& Berry, 2005); (Ladhari, 2008, p.172). That way, service quality would be easily measured.

In this study, service quality can be defined as the difference between customer's expectation for service performance prior to the service encounter and their perception of the service received. Customer's expectation serves as a foundation for evaluating service quality because, quality is high when performance exceeds expectation and quality is low when performance does not meet their expectation (Asubonteng et al., 2006). Expectation is viewed in service quality literature as desires or wants of consumer i.e., what they feel a service provider should offer rather than would offer (Parasuraman et al., 2008). Perceived service is the outcome of the consumer's view of the service dimensions, which are both technical and functional in nature (Gronroos, 1984). Service quality is an important dimension and is often linked to dimensions, namely, duration and affective content which play a vital role in comparing service encounters (Price, Arnould, \& Tierney, 2005). The authors suggested a framework that focused on service encounters that fell at the extreme of these three dimensions, named as extended, affectively charged and intimate (EAI) encounters. Utilizing qualitative and quantitative information, they advanced some measures of service provider performance and tested a structural model of the relationships among service provider performance, affective response and service satisfaction for EAI encounters. Chandon, Leo, \& Philippe (2007) proposed a dyadic approach that explored the multiple dimensions of the quality of service encounters and their evaluation from the two perspectives of customers and contact personnel.
Chandon, Leo, \& Philippe (2007) explains that companies must decide whether they intend to compete on the basis of low price or differentiation and whether they will target broadly across a number of market segments. This refers to speed, courtesy, competence and easy of repair. The consumers are not concerned about a product breaking down but also about the elapsed time before service is restored and the timeliness in which service appointment are kept. The nature of their dealings with the services personnel and the frequency with service calls/repairs fail to correct outstanding problems. In these case where problems are not immediately resolved, and complaints are filled in the company; if there are no procedures to handle the complaints there may be a possibility to affect the customers ultimate evaluation of product and service quality. Public sector services are responsible and accountable to citizens and communities as well as to its customers. In addition, Caron and Giauque (2006) pointed out that public sector employees are currently confronted with new professional challenges arising from the introduction of new principles and tools inspired by the shift to new public management.

\subsubsection{Service Delivery}

Service delivery framework is a set of principles, standards, policies and constraints used to guide the design, development, deployment, operation and retirement of services delivered by a service provider with a view to offering a consistent service experience to a specific user community in a specific business context. Service delivery framework is the context in which a service provider's capabilities are arranged into services (Helmsing, 2005). Oboth (2001) noted that in as far as the Local Government Act, the constitution and any other statutes that are studied, there is no definition of the phrase (service delivery) either deliberately or ignorantly. According to Oboth (2001), Service is a system or arrangement that supplies public needs whereas delivery is periodical performance of a service. Therefore service delivery is a system or arrangement of periodical performance of supplying public needs.

Helmsing (2005) in his study defines service delivery as a deliberate obligatory decision by the elected or appointed officials to serve or deliver goods and services to the recipients. Heskett (1987) defines service delivery as an attitudinal or dispositional sense, referring to the internationalization of even service values and norms. Customer care involves putting systems in place to maximize customers' satisfaction. It should be a prime consideration for every business sales and profitability depends on keeping your customers happy. It is more directly important in some roles than others. For receptionists, sales staff and other employees in customer-facing roles, customer care should be a core element of their job description and training, and a core criterion when recruiting (Athanassopoulos, 2000).

From the point of view of an overall sales process engineering effort, customer service plays an important role in an organization's ability to generate income and revenue. From that perspective, customer service should be included as part of an overall approach to systematic improvement. One of 
the most important aspects of a customer service Key Performance Indicators (KPI) is that of what is often referred to as the "Feel Good Factor". Basically, the goal is to not only help the customer have a good experience, but to offer them an experience that exceeds their expectations (Barnes, 2004).

\subsubsection{Health Strat}

HealthStrat (Health strategy) offer world class support services to governmental and non-governmental organizations in healthcare management which was formed in 2002. Utilizing its core competencies in continuous clinical quality improvement, community wellness systems, and health service systems, HealthStrat guarantees improved quality of care with the aim of attaining world class health outcomes for all (Parasuraman et al., 2008).

This strategy sets out the journey to develop a shared services organization to serve the emerging health environment. It has been approved by the Directorate of the HealthStrat following detailed deliberation by both the HealthStrat Leadership Team and a steering group established to support the strategy development process. Following the approval of the Directorate of the HealthStrat, it was time to move to implement the key actions contained within the strategy (Ladhari, 2009). There was an extensive engagement as part of the strategy preparation process including dialogue with staff of the HealthStrat and the voluntary sector, the Department of Health, Department of Public Expenditure and Reform as well as the unions. The creation of a shared service entity is a key support and enabler to the wider health reform. The reforms identified can be facilitated by a single supporting shared services infrastructure. The successful implementation of a shared services model will also avoid the risk of investment in duplicated support services across the country in the emergent organizational structures (Shahin, 2005).

HealthStrat has developed clinical quality monitoring tools that support its client's continuous clinical quality improvement systems. HealthStrat assists health providers collect and analyze data related to the quality, quantity and the effectiveness of services provided, should there be a gap in service provision, HealthStrat will facilitate implementation of activities to result in improved services. PSI is a competitor of HealthStrat which worked closely with the six main manufacturers of mosquito nets in Kenya as well as several large importers. HealthStrat believe that that the services a patient receives is only as good as the competency of the healthcare provider attending to them. Its in-house specialists utilize innovative training methodologies in training that focus on the competency of the healthcare provider rather than focusing on imparting pure knowledge (Chowdhary and Prakash, 2007). The health service generally faces a severe financial challenge because of multi-year reductions to its funding base resulting in a need for significant savings. Budget 2014 means that the health service will have an overall gross Vote reduction in 2014 of $€ 272 \mathrm{~m}$ and a savings target of $€ 619 \mathrm{~m}$. This challenge comes at a time when the demand for and costs of health and personal social services are increasing every year as a result of: An $8 \%$ increase in population since 2006 with a $14 \%$ increase in the number of people over 65 years of age; 1.8 million people ( $40 \%$ of the population) qualifying for medical cards, an increase of 590,000 or $46 \%$ since January 2008; The increasing burden of chronic disease management; advances in the development of medical technologies that, whilst welcome, are highly cost-intensive (Juanita et al., 2005; Parasuraman et al., 2008). The core frontline health services have been impacted in recent years by a diminishing administrative resource (2000 WTEs) at a time of higher than ever need for attention to administrative functions and a paucity of ICT investment.

The health service is developing an integrated portfolio of reform programmes to ensure that its core objectives to deliver for safe and effective health and social care services for patients, services users, carers and families in multiple settings are met. The shared services entity will serve all elements of the health system including the voluntary sector and will be driven by a strong awareness of client needs and the challenges facing the wider health environment. Successful delivery of this plan is dependent upon investment in people, systems and processes. The implementation of a national financial and procurement solution is a key priority along with the need to invest in pensions management, recruitment and CRM systems (Chowdhary and Prakash, 2007). The success of the shared service entity will be determined by its governing body, measuring both service performance and customer satisfaction. Third party benchmarks will be used to assess relative value over time. The changes being proposed in how we approach and resource the provision of shared services will be designed having due regard to the current health service context (Juanita et al., 2005).

\subsection{Problem Statement}

In today's global competitive environment delivering quality service is considered as an essential strategy for success and survival (Parasuraman et al., 2005). Even the public sector organizations have come under increasing pressure to deliver quality services (Randall and Senior, 2004) and improve efficiencies (Robinson, 2003). Customer needs and expectations are changing when it comes to governmental services and their quality requirements. However, service quality in public sector organizations is slow and is further exacerbated by difficulties in measuring outcomes, greater scrutiny from the public and press, lack of freedom to act in an arbitrary fashion and a requirement for decisions to be based in law. Studies have been done on service quality dimensions. For instance, Sureshchander et al, (2002) state that "The veritable gains of a quality revolution come only from customer delight, which again to a very great extent depends on the customer's perceptions of overall service quality. According to Douglas \& Connor, (2003), services are intangible in nature, evaluating the customer's perception of quality can be done through the interaction with the personnel offering services. Service quality is an important area to academicians because of its relevancy to service companies and therefore many researchers have tried to develop various 
models to measure it, even though some claim it is hard to measure because of its intangibility which is hard to quantify. From their suggestion, interaction between consumer and service provider is very important when measuring service quality because through that interaction, the service provider could easily understand the consumer better and identify what he/she exactly wants.

Several researchers have dealt with service quality (Brysland and Curry, 2001). Brysland and Curry (2001) stated that the literature clearly supported the use of SERVQUAL in the public sector. According to Gowan, Seymour, Ibarreche, \& Lackey (2001) service provision is more complex in the public sector because it is not simply a matter of meeting expressed needs, but of finding out unexpressed needs, setting priorities, allocating resources and publicly justifying and accounting for what has been done. In addition, Caron and Giauque (2006) pointed out that public sector employees are currently confronted with new professional challenges arising from the introduction of new principles and tools inspired by the shift to new public management. This study therefore intends to fill in the research gap since there is no study done on the relationship between service quality and service delivery. In this it would be important to ascertain the factors that determine service quality at Healthstrat? What are the customer's service expectations? and finally how service quality management practices impact on service delivery at Healthstrat?

\subsection{Research Objective}

i. To investigate the factors that determines service delivery at Healthstrat

ii. To investigate the customers' service expectations at Healthstrat

iii. To determine the impact of service delivery mechanism on service quality

\subsection{Value of the Study}

The findings from the study will particularly be useful in providing additional knowledge to existing and future organizations on service quality. The findings will also provide a useful reference document to stakeholders in the NGOs and Public Service in their endeavors to enhance Service quality to their customers. Additionally, the research will be helpful in identifying further areas of research built on its recommendations. To the academic field, the study may be a source of reference material for future research on other related topics. It will also help the policy makers within public and private sector to identify crucial areas in their organizations and make appropriate decisions to ensure that enhanced service quality.

\section{Literature Review}

\subsection{Theoretical Underpinning}

The SERVQUAL model is suitable for service quality dimensions in creating quality service delivery at Healthstrat.
This is because one cannot use a generic SERVQUAL model in this context since it may not be adequate to assess service quality in health sector and will not provide a good measure of customers' perceptions. Parasuraman et al., (2005), developed a model of service quality after carrying out a study on four service settings: retail banking, credit card services, repair and maintenance of electrical appliances, and long-distance telephone services. The SERVQUAL model represents service quality as the discrepancy between a customer's expectations of service offering and the customer's perceptions of the service received. According to Parasuraman et al., (2005) this makes it an attitude measure. What this model strives to measure exactly is the consumer perception of the service quality which depends on the size of the gap between expected service and perceived service which in turn, depends on the gaps under the control of the service provider such as delivery of service, marketing, (Parasuraman et al., 2005). This measurement of service quality is based on both on how consumer evaluates the service delivery process and the outcome of the service, (Parasuraman et al., 2005, p.42). A good service quality is considered as one which meets or exceeds consumer's expectation of the service (Parasuraman et al., 2005, p.46).

The SERVQUAL model was made of ten dimensions of service quality when created; tangibles, reliability, responsiveness, communication, credibility, security, competence, courtesy, understanding the customer, and access, Parasuraman et al., (2005, p.47-48) but later on these dimensions were reduced to five because some dimensions were overlapping (communication, credibility, security, competence, courtesy, understanding customers and access) and they included, Tangibles- physical facilities, equipment, and staff appearance. Reliability- ability to perform the promised service dependably and accurately; Responsivenesswillingness to help customers and provide prompt service.

Assurance- knowledge and courtesy of employees and their ability to inspire trust and confidence; Empathy- caring, individual attention the firm provides its customers (Parasuraman et al., 2008, p.23).

These dimensions mainly focus on the human aspects of service delivery (responsiveness, reliability, assurance, and empathy) and the tangibles of service. According to study carried out by Ladhari, (2009), it is recommended that the SERVQUAL model is a good scale to use when measuring service quality in various specific industries but that it is appropriate to choose the most important dimensions of this model that fit to that particular service being measured in order to assure reliable and valid results. In this regard, we will use this model because it takes into account customer's expectation of a service as well as perceptions of the service which is best way to measure service quality in service sector (Shahin, 2005). Buttle, (2006) makes mentions of several researchers that have used the SERVQUAL model in various industries (retailing, restaurants, banking, telecommunication industry, airline catering, local government, hotels, hospitals, and education). He further suggests that service quality has become an important topic because of its apparent relationship 
to costs, profitability, customer satisfaction, customer retention and positive word of mouth and it is widely considered as a driver of corporate marketing and financial performance.

\subsection{Health Care Sector in Kenya}

According to World Health Organization, the total health expenses are the sum devoted to the public and private health sectors. It covers the provision of health services (preventive and curative), the family planning activities, the nutrition activities, and the emergency aid designated for health but does not include provision of water and sanitation. Health Financing in Kenya: The Case of RH/FP in Kenya found that the estimates of Ministry of Health expenditures between 2005/06 and 2009/10 grew from Ksh 30 billion to Ksh 47 billion, as shown in Table 1 below. This represents an overall growth of $56 \%$. As a percentage of the Government of Kenya's (GOK) total budgets, the expenditures remain low at $5.3 \%$ in 2009/10 - almost eight years after the government committed itself to increasing this ratio to $15 \%$ by signing the Abuja Declaration. Yet, there are signs of improvement, as the Mid-term Expenditure framework for 2009-2010 indicate that the government intends to increase allocation to the health sector consistently in the two upcoming financial years.

The health sector in Kenya relies on several sources of funding: public (government), private firms, households and donors (including faith based organizations and NGOs) as well as health insurance schemes (Ministry of Health Kenya, 2011). The GOK funds the health sector through budgetary allocations to the $\mathrm{MOH}$ and the MOPHS and related government departments. As far as government spending is concerned, the Ministry of Finance sets three year budget ceilings for each sector in Kenya. In practical terms this means that the Ministry of Health creates a budget based on what the Ministry of Finance has said it will allocate for health expenditures rather than submitting a budget request based on actual needs. The Ministry of Health then disburses the funds it receives through its District Health Management Boards. The health budget shortfalls are manifest in the widespread lack of adequate drugs and pharmaceuticals, staff shortages and poor maintenance of equipment, transport, and facilities (Ministry of Health Kenya, 2011). Kenya depends significantly on donor funds, many of which supplement the development component of the national health budget. In $2009 / 10$, on-budget external resources accounted for $15.1 \%$ of all health spending in Kenya, or Kshs 7.1 million. In 2005/06, Kenya's health budget was made up to $11.3 \%$ by donor contributions. Over the years, Kenya's health sector has increased its dependency on external sources.

Kenya's health care system is structured in a step-wise manner so that complicated cases are referred to a higher level. Gaps in the system are filled by private and church run units. The structure thus consists: Dispensaries and private clinics, Health Centres, Sub-district hospitals and nursing homes, District hospital and private hospitals, Provincial hospitals and National hospitals. Health care expenditure in the SSA varies substantially over time and across countries. Health financing is important for the improvement of health status in any economy. At the macroeconomic level, the level and growth of health care expenditure has been attributed to the income level of such country (Ministry of Health Kenya, 2011). The performance of the health sector is therefore assumed to reflect the size of the income elasticity of health care.

\subsection{Service Quality}

According to Parasuraman, Zeithaml and Berry (2005). Service quality is defined as a comparison of customer expectations with service performance. The organizations with high service quality meet the customer needs and also remain most economical in terms of competition as improved service quality also makes the firm more competitive. High service quality is achieved by knowing operational process through identifying problems in service and defining measures for service performances and outcomes as well as level of customer satisfaction.

Initial efforts in defining and measuring service quality emanated largely from the goods sector, research work in the area of service quality was laid down in the mid-eighties by Parasuraman, Zeithaml and Berry (2005). These were amongst the pioneer researchers to point out that the concept of quality prevalent in the goods sector is not extendable to the services sector. They noted that services were intangible and needed a distinct framework for evaluation as opposed to goods sector where tangible cues exist to enable consumers evaluate product quality. Quality in the services context falls in the realm of experience and credence, properties which are complex to measure and evaluate objectively (Parasuraman, Zeithaml and Berry, 2005; Zeithaml and Bitner, 2001). The contributions made by Parasuraman, Zeithaml and Berry (2008) in their studies on service quality have continued to shape the direction of research in the services sector.

Service is a series of behaviours, processes and performances (Zeithaml and Bitner, 2006). Delivering quality service is an essential strategy for success and survival in today's competitive environment (Dawkins and Reichheld, 2000). According to Parasuraman et al., (2005), early studies during 1980s focused on determining what service quality meant to customers and developing strategies to meet customer expectations. Service quality has also attracted the attention of researchers all over the world (Chowdhary and Prakash, 2007). However, most of the research has focused on measuring service quality using the SERVQUAL instrument (Parasuraman et al., 2005). Parasuraman et al., (2008) stated that the factors for assessing service quality could be categorized into five service quality dimensions which include tangibility (the physical evidence of the service such as physical facilities and appearance of personnel), reliability(consistency of performance and service dependability), responsiveness (the willingness or readiness of employees to provide prompt service), assurance (knowledge and courtesy of employees and their ability to inspire trust and confidence) and empathy (caring, individualized attention the firm provides its customers). Many researchers have been using two methods in measuring 
service quality (Juanita et al., 2005).

\subsubsection{Management of Service Quality}

The introduction of customer and consequent emphasis on continuous improvement in management is one aspect that distinguishes Quality Management from the classical, human relations, systems and contingency theories. Quality Management bridges the gap between classical and human relations theories by introducing the aspect of customer to both sides (Clinton, Williamson, and Bethke, 2004). It introduces changes in the organizational systems that align the social and technical systems. It is a customer focused management paradigm shaped by beliefs relating to quality, measurement, product positioning, product design and key stakeholder. According to Ho, (2009) customer focused management paradigm, quality is viewed as one component of the value created for the customer. It is managed in to the process of making the product or service and is seen as synergistic with cost and delivery. Service quality is viewed as something that encompasses the entire organization. Since all functions are responsible for product quality and all share the cost of poor quality, quality is viewed as a concept that affects the entire organization.

\subsubsection{Dimensions of Service Quality}

Hill and Wilkinson (2000) came up with eight major dimensions of quality. These dimensions refers to the primary operation characteristics of product e.g. clarity of a television. In the services industry, speed and time are good measures. It combines both user and based approaches to the difference of quality. Measureable products and services attributes are involved and brands can be ranked objectively on at least one dimension of performance. The connection between quality and performance is also dependent circumstances. In the SERVQUAL model: reliability, responsiveness, competence, access, courtesy, communication, credibility, security, understanding the customer and tangibles. A customer's expectation of a particular service is determined by factors such as recommendations, personal needs and past experiences. The expected service and the perceived service sometimes may not be equal, thus leaving a gap. The service quality model or the 'GAP model' developed by a group of authors- Kevin, Kristine and Berry at Texas and North Carolina in 1985, highlights the main requirements for delivering high service quality. It identifies five 'gaps' that cause unsuccessful delivery. Customers generally have a tendency to compare the service they 'experience' with the service they 'expect'.

Common measures of reliability are the mean time of fast and the failure rate per unit time. Because measures require a product to be used for some time, they are more relevant to product and services that are consumed instantly. Customers do not alias possess complete information about a product or service attribute. Frequently indirect measures are the only basis for comparing brands. Product durability can only be inferred from various tangible and intangible aspects of product. In such circumstance signaling device become important influence about quality. Such things are images, advertising and brand names giving a perception of quality rather than reality itself. They can be however critically as exemplified in product details of manufacture, the distributor as well as the reputation of above Nigel, Stuart, and Robert, (2007).

\subsection{Service Delivery}

Service delivery is a deliberate obligatory decision by the elected or appointed officials to serve or deliver goods and services to the recipients. Service delivery framework is a set of principles, standards, policies and constraints used to guide the design, development, deployment, operation and retirement of services delivered by a service provider with a view to offering a consistent service experience to a specific user community in a specific business context. Service delivery framework is the context in which a service provider's capabilities are arranged into services (Helmsing, 2005). Helmsing (2005) in his study defines service delivery as a deliberate obligatory decision by the elected or appointed officials to serve or deliver goods and services to the recipients. Heskett (1987) defines service delivery as an attitudinal or dispositional sense, referring to the internationalization of even service values and norms. Customer care involves putting systems in place to maximize your customers' satisfaction with your business. It is more directly important in some roles than others. For receptionists, sales staff and other employees in customer-facing roles, customer care should be a core element of their job description and training, and a core criterion when you're recruiting (Athanassopoulos, 2000).

Factors affecting Service Delivery

Poor service delivery and governance remains an overwhelming challenge in most African countries and factors attributed to be affecting local governments include the following among other:

Infrastructure affects greatly on service delivery. For instance, in Kenya, the provision of better infrastructures has lagged behind over years. There are poor roads and inadequate electricity supply and hence Kenya still stands in need of better infrastructures (Proceedings of National Investment Conference, 2003). Public procurement, at the local government level, is believed to be one of the principle areas where corruption in Kenya takes place ("National Public Procurement Integrity Baseline Survey," 2006). Corruption is disastrous to the sound functioning of any government department. Corruption has been an intractable problem in many developing countries; especially where it has become systematic to the point where many in government have a stake. It diverts decision- making and the provision of services from those who need them to those who can afford them (Langseth, Kato, Kisubi \& Pope, 2007).

Lawal (2000) further asserts that corruption has been rampant among the senior civil bureaucrats to whom the public funds meant for developmental purposes are entrusted. Generally, wide-scale embezzlement by officials of the grassroots has made the needed development of the grassroots a tall dream and has rendered them financially 
incapable to discharge their constitutionally assigned responsibilities hence compromising service delivery. At every stage of public procurement, there are risks of integrity. During the pre-bidding period; starting from needs assessment, common risks include lack of adequate needs assessment, planning and budgeting of public procurement, requirements that are not adequately or objectively defined, an inadequate or irregular choice of the procedure and a timeframe for the preparation of the bid that is insufficient or not consistently applied across bidder s (OECD, 2007). All these concern the function of procurement planning. Should local government's procurement system fail to manage these risks, accountability and eventual service delivery is seriously threatened.

Despite the increase in the total amount of funds available to local government in Kenya, its economic and financial profile is still poor as compared to the development programme it is expected to carry out. This situation is not unconnected to the mismanagement and embezzlement of these funds by the local councils (Bailey, 2008). Ahmed (2005) further noted that many local governments in Kenya, however, are unable to deliver services to residents. He said this might be because of lack of finances or lack of capacity to provide a good service at an affordable price. So local governments should find other ways to ensure that the services are improved and reach the people most in need of them.

The other contributing factor is that local ward committees are not fully operational, resulting in poor communication with communities. Ward committees have been the focus of considerable attention by government as well civil society, with substantial investment already made in an attempt to ensure that these structures have the necessary capacity and resources required for them to fulfill their envisaged roles as the voices of communities (Langseth, 2007). At the same time, questions that are often asked are how effective are these institutions; whether they are useful conduits for community involvement in local governance; whether, as created space for public participation, they are inherently capable of playing the critical role expected of them towards service delivery. Indiscipline is rampantly perceived and well pronounced among the workers in local government (Hernon \& Whitman, 2001). They further said that senior officers who travel to their families away from their offices on Friday return very late the following Monday or may decide to stay back till Tuesday; and the junior members of staff who directly or indirectly observe this more often than not are in the habit of playing truant with their jobs. Little or no commitment to duty has become a rule rather than an exception. Hard-earned and limited resources accrued to and raised by local government are always mismanaged. Priorities are misplaced; projects are done not according to or as demanded by the people but regrettably in tune with the selfish end and aggrandizement of the political leadership in collaboration with the senior bureaucrats at the local government level of administration (Johan, 2006).

\section{Research Methodology}

\subsection{Research Design}

The research adopted a descriptive survey to gather data. Kombo and Tromp (2006) define a descriptive survey as a method of research which gathers data at a particular point in time with the intention of describing the nature of existing conditions of, or determining specific information. Kothari (2004) recommends descriptive design as it allows the researcher to describe, record, analyze and report conditions that exist or existed. The research questions were answered using a mixed method of study design. This involved collecting, analyzing and interpreting both qualitative and quantitative data in the same study or in a series of studies that investigate the same underlying phenomenon. It involved description of the data, in words and tables in order to demonstrate whether there is statistical relationship or merely descriptive in order to answer the research questions in the study.

\subsection{Sampling Procedure and Sample Size}

Sampling means selecting a given number of subjects from a defined population as representative of that population. The choice of sample size is as important as is the choice of sampling scheme. This is because it determines the extent to which the researcher can make statistical or/ and analytical generalizations (Onwuegbuzie \& Leech, 2004). Mugenda and Mugenda (2003), states that a sample of $30 \%$ is considered representative for a population of less than 500 . (30\% of $98=$ 30)

\subsection{Data Collection Method}

After the validity and reliability of the instruments were assessed, the researcher proceeded to the field. A permission letter to carry out the study in the area was sought from the National Council of Science and Technology. These letters helped the researcher to access the Organization, brief the head of operations on the purpose of the study and remove any important information by the managers. The researcher then sought to administer the questionnaires to the respondent and a drop and pick later method was used.

\subsection{Data Analysis}

Data collected from respondents was processed and analyzed. According to Kothari, (2004) this is essential for a scientific study and for ensuring that all relevant data for making contemplated comparisons and analysis are available. The process comprised of; editing which involved examination of raw data to detect errors and omissions in questionnaires and to make corrections where possible; coding which involved assigning numerals to answers so that responses can be classified into a limited number of categories appropriate to the research problem under consideration; classification which involved reducing the data into homogenous groups according to attributes or in class intervals; tabulation which is essentially displaying the data in compact form. A descriptive analysis of 
the data after processing involved computing mean, mode and median with the help of Statistical Package of Social Sciences Software (SPSS) and Microsoft Excel and presented in frequency tables and charts.

\section{Empirical Results and Discussion}

\subsection{Response Rate}

The analysis was done by analyzing questionnaires collected from employees working at the hospitals that Healthstrat supports. A total of 30 questionnaires were distributed and total of 26 questionnaires were duly filled and collected making an $86.9 \%$ response rate. This was an acceptable rate and could be attributed to the fact that the questionnaires were physically dropped to the respondents and collected at an agreed date.

\subsection{Demographic Characteristics}

The study sought to establish the information on the respondents employed in the study with regards to the gender, age, their level of education and duration of service. These bio data points at the respondents' appropriateness in responding to the study questions required for the study to be complete.

\subsubsection{Gender of the Respondents}

The respondents were asked to indicate their gender, this was expected to guide the researcher on the conclusions regarding the degree of congruence of responses with the gender characteristics on service quality at Healthstrat. The results of the study are presented in the figure below.

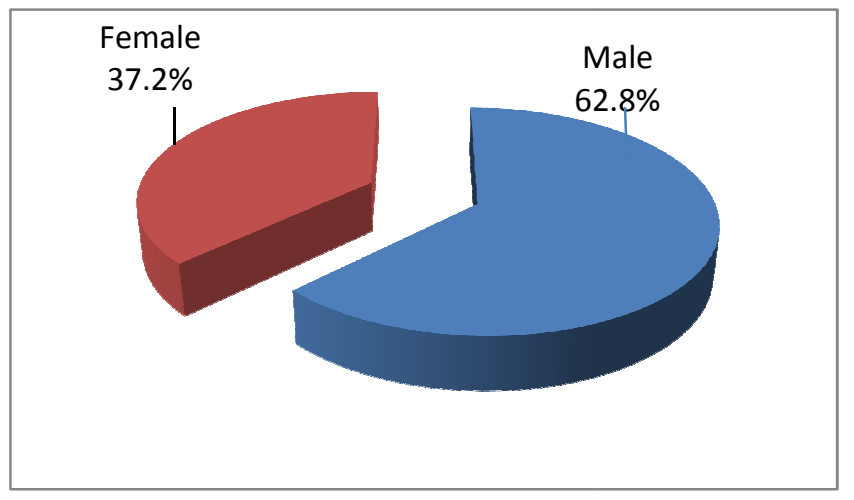

Figure 4.1. Gender of the Respondents.

The results as shown in the figure 4.1 show that majority of the respondent were male at $63 \%$ while female was $37 \%$. The results indicate that majority of the employees working at the hospitals that Healthstrat supports in Kenya are men.

\subsubsection{Respondents' Age Group}

This area of the study, the researcher sought to know the age category of the respondents. This was expected to guide the researcher in understanding the most active age group in regards to service quality in Healthstrat. Figure 4.2 shows that the study findings.

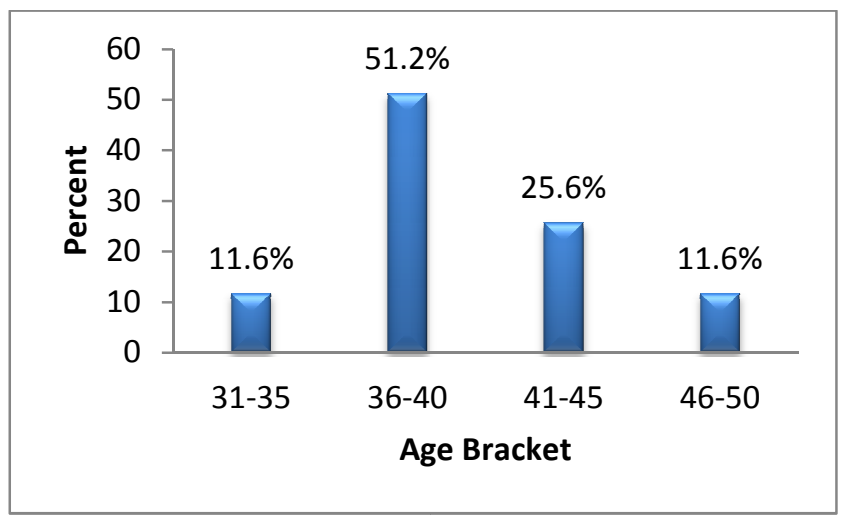

Figure 4.2. Age Bracket of the Respondents.

On age category, $11.6 \%$ of respondents were aged between 31-35 years, $51.2 \%$ were aged $36-40$ years, $25.6 \%$ were aged above $41-45$ years and the rest of the respondents $11.6 \%$ were aged between $46-50$ years. From these findings, most of the respondents working at the hospitals that Healthstrat supports in Kenya belong to an age category of 36-40 years. This is the most active age group hence they are actively involved in service delivery and have rich experience.

\subsubsection{Level of Education}

Figure 4.3 indicates the study results of the respondents' level of education. This was to help the researcher understand the level of education of the employees working at the hospitals that Healthstrat supports in Kenya.

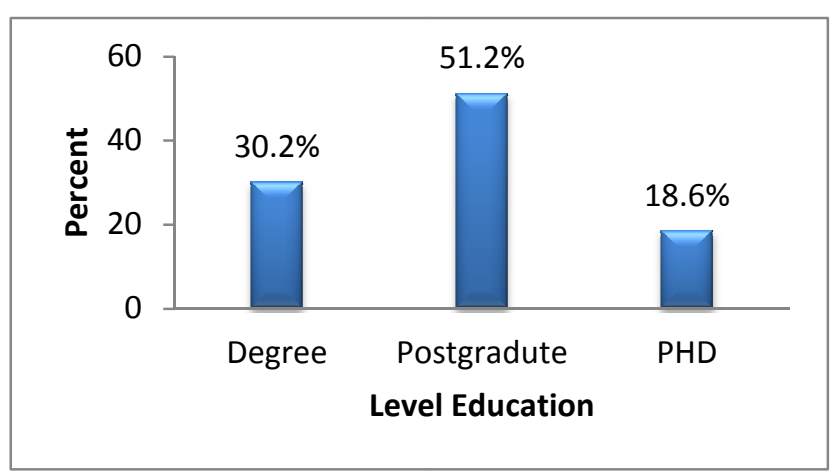

Figure 4.3. Education Level of the Respondents.

The study findings indicate that $30.2 \%$ of the respondents are first degree holders, $52.3 \%$ are postgraduate degree holders and $18.6 \%$ had PhDs. All employees working at the hospitals that Healthstrat supports were found to be degree holders and therefore it can be assumed that the respondents provided information based on the academic knowledge, skills and experience they have gained over the years.

\subsection{Factors Determining Service Quality}

The study in this part aimed at identifying the extent at which the following factors affect service quality in the organization. Data was collected using linkert scale of No extent (1), Little extent, (2), Moderate extent (3), Large extent (4) and Very large extent (5). The table below shows the research findings. 
Table 4.1. Factors Determining Service Quality.

\begin{tabular}{|c|c|c|}
\hline Statements & Mean & $\begin{array}{l}\text { Std. } \\
\text { Deviation }\end{array}$ \\
\hline $\begin{array}{l}\text { Quality is very important in my work expectations } \\
\text { of disciplines/areas my unit deals with }\end{array}$ & 2.8372 & .37097 \\
\hline $\begin{array}{l}\text { Quality standards are clearly defined for each } \\
\text { division of the hospital }\end{array}$ & 2.7442 & .48961 \\
\hline $\begin{array}{l}\text { I expect management to set standards for quality } \\
\text { service }\end{array}$ & 2.4419 & .33356 \\
\hline $\begin{array}{l}\text { Regard held for your professional skill - seen as } \\
\text { much more important to Medical and Allied Health } \\
\text { staffs }\end{array}$ & 3.1628 & .47372 \\
\hline $\begin{array}{l}\text { Information is regularly collected about the service } \\
\text { quality expectations of disciplines/areas my unit } \\
\text { deals with }\end{array}$ & 3.0465 & .34548 \\
\hline $\begin{array}{l}\text { I expect to be able to measure the quality of service } \\
\text { from other disciplines/areas }\end{array}$ & 2.9302 & .43269 \\
\hline $\begin{array}{l}\text { I tend to be more critical when evaluating work } \\
\text { quality of people I work with on a regular basis } \\
\text { than those I work with on an irregular basis }\end{array}$ & 3.0000 & .38680 \\
\hline $\begin{array}{l}\text { My work quality is formally assessed as part of my } \\
\text { performance appraisal }\end{array}$ & 3.4419 & .29589 \\
\hline
\end{tabular}

From the research findings, assessment of work quality as part of performance appraisal had the highest mean score at 3.4419. This signifies that it is the most important factor that determines service quality. Other significant factors are regular collection of information on service quality (mean = 3.0465) and critical evaluation of the work quality of people (mean=3.0). Less significant factor was employee expectations on management to service quality standard (mean=2.4). The study aimed at identifying the extent at which the following factors affect service quality for service delivery at Healthstrat. On service quality, assessment of work quality as part of performance appraisal had the highest mean score at 3.4419. This signifies that it is the most important factor that determines service quality. Other significant factors are regular collection of information on service quality and critical evaluation of the work quality of people. According to Parasuraman, Zeithaml and Berry (2005, an organizations with high service quality meet the customer needs and also remain most economical in terms of competition as improved service quality also makes the firm more competitive. High service quality is achieved by knowing operational process through identifying problems in service and defining measures for service performances and outcomes as well as level of customer satisfaction.

\subsection{Customers' Service Expectations at Healthstrat}

Respondents were asked their views on how dimensions of quality influenced the service delivery at Healthstrat. They were requested to rate with a degree of agreement/ disagreement using a scale of 1-5, by ticking their appropriate choice. The table below shows the research findings.

Table 4.2. Customers' Service Expectations at Healthstrat.

\begin{tabular}{lll}
\hline Factors Under Consideration & Mean & $\begin{array}{l}\text { Std. } \\
\text { Deviation }\end{array}$ \\
\hline $\begin{array}{l}\text { Tangibles at Healthstrat -Appearance of physical } \\
\text { facilities, equipment, personnel, and }\end{array}$ & 3.4419 & .29589 \\
\hline
\end{tabular}

\begin{tabular}{lcc}
\hline Factors Under Consideration & Mean & $\begin{array}{l}\text { Std. } \\
\text { Deviation }\end{array}$ \\
\hline $\begin{array}{l}\text { communication materials } \\
\begin{array}{l}\text { Reliability at Healthstrat -Ability to perform the } \\
\text { promised service dependably and accurately }\end{array}\end{array}$ & 3.3953 & .25971 \\
$\begin{array}{l}\text { Responsiveness at Healthstrat -Willingness to help } \\
\text { customers and provide prompt service }\end{array}$ & 3.0930 & .31760 \\
$\begin{array}{l}\text { Assurance at Healthstrat -Knowledge and courtesy } \\
\text { of employees and their ability to convey trust and } \\
\text { confidence }\end{array}$ & 3.3488 & .38604 \\
$\begin{array}{l}\text { Empathy at Healthstrat -Caring, individualized } \\
\text { attention the firm provides its customers }\end{array}$ & 3.4186 & .36306 \\
\hline
\end{tabular}

From the study findings, most respondents were in agreement that appearance of physical facilities, equipment, personnel, and communication materials is what customers highly regard about service with a mean score of 3.4. Other significant factors were reliability -ability to perform the promised service dependably and accurately, assurance -knowledge and courtesy of employees and their ability to convey trust and confidence and empathy -caring, individualized attention the firm provides its customers. The least important factor was responsiveness -willingness to help customers and provide prompt service with a mean score of 3.0930. On customers' service expectations, respondents were in agreement that appearance of physical facilities, equipment, personnel, and communication materials is what customers highly regard about service with a mean score of 3.4. They also agreed that reliability -ability to perform the promised service dependably and accurately, assurance -knowledge and courtesy of employees and their ability to convey trust and confidence and empathy -caring, individualized attention the firm provides its customers. This contends with a study by Parasuraman et al., (2005), who argues that service quality meant to customers and developing strategies to meet customer expectations. Service quality has also attracted the attention of researchers all over the world (Chowdhary and Prakash, 2007). However, most of the research has focused on measuring service quality using the SERVQUAL instrument.

\subsection{Service Delivery Mechanism on Service Quality}

Respondents of the study were asked to rate the extent at which the following factors conform to service delivery mechanism on service quality in their respective organization. The table below shows the research findings.

The results in Table 4.3 indicates that, understanding the customer in making an effort to know customers' needs and responsiveness has a significantly positive influence on service delivery mechanism on service quality with a mean score of 3.4419. This signifies that they are the most important factors that determine service quality mechanism on service quality. Other significant factors are assurance, collaboration as a notion of teamwork and working together for patient outcomes and competence is seen as possession of the required skills and knowledge to perform the service (mean=3.0). Less significant factor were triadic communication network interposed between patients and family and equity as a sense of fairness in how the actions of others impact on the individual concerned (mean=2.4). On 
service delivery mechanism on service quality, understanding the customer in making an effort to know customers' needs and responsiveness has a significantly positive influence on service delivery mechanism on service quality with a mean score of 3.4419. Helmsing (2005) in his study defines service delivery as a deliberate obligatory decision by the elected or appointed officials to serve or deliver goods and services to the recipients. Service delivery framework is therefore a set of principles, standards, policies and constraints used to guide the design, development, deployment, operation and retirement of services delivered by a service provider with a view to offering a consistent service experience to a specific user community in a specific business context. Service delivery framework is the context in which a service provider's capabilities are arranged into services (Helmsing, 2005).

Table 4.3. Service Delivery Mechanism on Service Quality.

\begin{tabular}{lll}
\hline Service Delivery Mechanism & Mean & $\begin{array}{l}\text { Std. } \\
\text { Deviation }\end{array}$ \\
\hline $\begin{array}{l}\text { Reliability has a significantly positive influence on } \\
\text { service delivery }\end{array}$ & 2.9628 & .37372 \\
$\begin{array}{l}\text { Tangibility has a significantly positive influence on } \\
\text { service delivery }\end{array}$ & 3.0465 & .44548 \\
$\begin{array}{l}\text { Triadic communication network interposed } \\
\text { between patients and family }\end{array}$ & 2.9302 & .23269 \\
$\begin{array}{l}\text { Competence is seen as possession of the required } \\
\text { skills and knowledge to perform the service }\end{array}$ & 3.0000 & .28680 \\
$\begin{array}{l}\text { Responsiveness has a significantly positive } \\
\text { influence on service delivery }\end{array}$ & 3.4419 & .39589 \\
$\begin{array}{l}\text { Collaboration as a notion of teamwork and } \\
\text { working together for patient outcomes }\end{array}$ & 3.2558 & .38961 \\
$\begin{array}{l}\text { Equity as a sense of fairness in how the actions of } \\
\text { others impact on the individual concerned. }\end{array}$ & 2.9302 & .30357 \\
$\begin{array}{l}\text { Understanding the customer in making an effort to } \\
\text { know customers and their needs }\end{array}$ & 3.4419 & .29589 \\
$\begin{array}{l}\text { Assurance has a significantly positive influence on } \\
\text { service delivery }\end{array}$ & 3.3953 & .35971 \\
\hline
\end{tabular}

Using a scale $1-5$, respondents were asked to rate the extent of disagreement/disagreement of the extent of service quality at healthstrat. The table below shows the research findings.

Table 4.4. Service Quality.

\begin{tabular}{|c|c|c|}
\hline Service Quality & Mean & $\begin{array}{l}\text { Std. } \\
\text { Deviation }\end{array}$ \\
\hline $\begin{array}{l}\text { High service quality is achieved by knowing } \\
\text { operational process }\end{array}$ & 4.3953 & .25971 \\
\hline $\begin{array}{l}\text { Improvement in service design and delivery helps } \\
\text { achieve higher levels of service delivery }\end{array}$ & 4.0930 & .31760 \\
\hline $\begin{array}{l}\text { There are measures put in place to check service } \\
\text { quality at healthstrat }\end{array}$ & 4.3488 & .38604 \\
\hline
\end{tabular}

From the research findings, respondents strongly agreed that; High service quality is achieved by knowing operational process with a mean of 4.3 , improvement in service design and delivery helps achieve higher levels of service delivery $($ mean $=4.0)$ and that there are measures put in place to check service quality at healthstrat with a mean score of 4.34 .

\section{Conclusions and Recommendations}

\subsection{Conclusions}

First of all it can be concluded that service quality as perceived by customers is as a result of how well service matches expectations. Secondly that service quality was determined by two dimensions, namely; expectations and experience and each of these dimensions had underlying factors. Thirdly, five factors determined the outcome of service quality which is used by the customers to complete judgement during service delivery, namely; tangibles, reliability, responsiveness, assurance and empathy. According to Ho, (2009) customer focused management paradigm, quality is viewed as one component of the value created for the customer. It is managed in to the process of making the product or service and is seen as synergistic with cost and delivery. Service quality is viewed as something that encompasses the entire organization. Since all functions are responsible for product quality and all share the cost of poor quality, quality is viewed as a concept that affects the entire organization.

Furthermore, the actual management of service quality depends on how well the gaps presented by Zeithaml et al. (1988) are managed. Each gap is a representation of a lack of focus on resources resulting in negative effects towards service quality. First of all it starts with management's perception of desired service quality by customers through analyzing customer expectations and demand analysis and based on their perception design specifications for service quality and these are then followed on by contact employees during service delivery. The study further concludes that customer satisfaction should be measure, once a year with the customer satisfaction index. Further, spontaneous feedback should be reviewed regularly. Even though spontaneous feedback isn't always that realistic, because one receive something when the customer is satisfied or when they aren't. So what lies in between you don't find out. That is why the customer satisfaction index that we have once a year, because this does measure all the points where service are delivered.

\subsection{Recommendations}

For future implications, this study would have to be done again, this time involving much more participants as well as involving one strategic manager and one operational manager into the study. Secondly, within this study it was argued which factors, namely; functional quality or technical quality was more important than the other. Although most of the participants mentioned that it's the functional quality which has the most effect on the outcome of the service delivery because of the human element. A separate study on this subject would shed light on which element is more important and could provide more focus for improving service quality. Last but not least, the last part of the interview covered the subject of focus for improving service quality. All participants mentioned the staff to be the focus of improvement based on the fact that it's the service staff that actually operationalizes 
service quality standards and more importantly it's during the service encounter where the customer forms the last judgments on service quality. This part can be applied to the importance of the human resource in daily operations. The importance of contact employee and how much improvement can be seen if more focus is given to employees.

\section{Acknowledgements}

I take this opportunity to thank God for taking me through this study and for giving me the strength to go through the whole programme. I would also like to register my appreciation to the entire body and management of University of Nairobi for giving me the opportunity to undertake my studies at the institution.

\section{References}

[1] Asubonteng, P., McCleary, K.J. \& Swan, J.E. (2006). SERVQUAL revisited: a critical review of service quality, The Journal of Services Marketing, Vol.10, Number 6, p.62-81.

[2] Athanassopoulos A.D.,(2010) Customer Satisfaction Cues To Support Market Segmentation and Explain Switching Behaviour, Journal of Business Research, Volume 47, Issue 3, Pages 191-207, 2000

[3] Brysland, A. \& Curry, A. (2001) Service Improvements in public services using SERVQUAL, Managing Service Quality, vol. 11(6), p. 389-401

[4] Caron, Daniel J. \& Giauque, David (2006) Civil servant identity at the crossroads: new challenges for Public administrations, International Journal of Public Sector anagement, vol. 19(6), p. 543-555

[5] Chandon, J.L., Leo, P.Y. \& Philippe, J. (2007) Service encounter dimensionsĐ a dyadic perspective: Measuring the dimensions of service encounters as perceived by customers and personnel, International Journal of Service Industry Management, 8 , pp. $65 \pm 86$.

[6] Clinton, R.J., Williamson, S. and Bethke, A.L. (2004). Implementing total quality management: The role of human resource management, SAM Advanced Management Journal, 59(2), pp. 10-17.

[7] Eshghi, A., Roy, S. K., \& Ganguli, S. (2008). Service quality and customer satisfaction: An empirical investigation in Indian mobile Telecommunications services, Marketing Management Journal, Vol 18, Number 2, p. 119-144.

[8] Ghylin, K.M., Green, B. D., Drury, C. G., Chen, J., Schultz, J.L., Uggirala, A., Abraham, J.K. \& Lawson, T.A. (2006). Clarifying the dimensions of four concepts of quality, Theoretical Issues in Ergonomics Science, Vol. 9, Number 1, p.73-94.

[9] Gowan, M., Seymour, J., Ibarreche, S. \& Lackey, C. (2001) Service quality in a public agency: same expectations but different perceptions by employees, managers, and customers, Journal of Quality Management, vol. 6, p. 275-291
[10] Gronroos, C. (1982). A service quality model and its marketing implications, European Journal of Marketing, Vol.18, Number 4, p.36-44.

[11] Helmsing, A. H. J. (2005). Local Government Central Finance. An Introduction: New York USA.

[12] Hill S. (1981). "Why Quality Circles Failed but Total Quality Management Might Succeed.” British Journal of Industrial Relations, 29(4), 541-568.

[13] Ho, S.K.M. (2009). From TQM to business excellence, Production Planning \& Control, 10(1), pp. 87-97.

[14] Hyde, A. (2002). "The Proverbs of Total Quality Management: Recharting the Path to Quality Improvement in the Public Sector." Public Productivity and Management Review, 16(1), 25-37.

[15] Kombo, D.K., \& Tromp, D.L. (2006). Proposal and Thesis Writing. Nairobi, Pauline.uwi.edu/pdf.

[16] Kothari, C. R. (2004). Research Methodology. New Delhi: Willy Eastern Limited.

[17] Ladhari, R. (2009). A review of twenty years of SERVQUAL research, International Journal of Quality and Service Sciences, Vol. 1, Number 2. P.172-198.

[18] Mentzer, J. (2006), Fundamentals of Supply Chain Management, Response Books

[19] Negi, R. (2009). Determining customer satisfaction through perceived service quality: A study of Ethiopian mobile users, International Journal of Mobile Marketing; Vol.4, Number 1; p.31-38.

[20] Nigel, S., Stuart, C., and Robert, J. (2007). Operations Management. Prentice Hall, Pearson Education

[21] Oboth, M. J. (2001). Decentralization and Service Delivery: Constraints and Controversies. Kampala: Makerere University Library.

[22] Parasuraman, A., Zeithaml, V. A., \& Berry, L. L. (2005). A conceptual model of service quality and its implications for future research, Journal of Marketing, Vol. 49, p.41-50.

[23] Parasuraman, A., Zeithaml, V. A., \& Berry, L. L. (2008). SERVQUAL: A multiple-item scale for measuring consumer perceptions of service quality, Journal of Retailing, Vol. 64, Number 1, p.12-40.

[24] Price, L.L., Arnould, E.J. \& Tierney, P. (2005) Going to extremes: managing service encounters and assessing provider

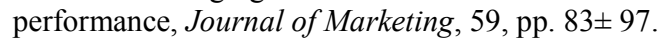

[25] Richard, B. C., Robert, J.F., Nicholas, J. A., and Nitin, K.A.(2007). Operations Management for Competitive Advantage. McGraw - Hill

[26] Sankey, H. (2007) "Kuhn's ontological relativism," in Issues and Images in the Philosophy of Science: Scientific and Philosophical Essays in Honour of Azarya Polikarov. Boston studies in the philosophy of science, vol. 192, pp. 305-320.

[27] Slack N., Chambers S., Johnstone R. (2008) Operations Management. $5^{\text {th }}$ Edition FT. Prentice Hall. 